REFERENCES

Amer. Rev. resp. Dis., 1963, 88, part 2

Badger, G. F., Dingle, J. H., Feller, A. E., Hodges, R. G., Jordan, W. S., jun., and Rammelkamp, C. H., jun. (1953). Amer. F. Hyg., 58, 174. Banatvala, J. E., Anderson, T. B., and Reiss, B. B. (1964). Brit. med. F., 1, 537.

Buck, C.' (1956). Amer. F. Hyg., 63, 1.

Chanock, R. M., Bell, J. A., and Parrott, R. H. (1961). In Perspectives in Virology, edited by $M$. Pollard, 2, 126. Chapman and Hall, London.

- Parrott, R. H., Cook, K., Andrews, B. E., Bell, J. A., Reichelderfer, T., Kapikian, A. Z., Mastrota, F. M., and Huebner, R. J. (1958). New Engl. F. Med., 258, 207. Clarke, S. K. R., Corner, B. D., Gambier, D. M., Macrae, J., and
Peacock, D. B. (1964). Brit. med. F., 1, 1536.

Dimmock, N. J., and Tyrrell, D. A. J. (1962). Lancet, 2, 536.
Gamble, D. R., and Kinsley, M. L. (1963). Mth. Bull. Minist. Hlth Lab. Serv., 22, 6.

Gardner, P. S., Stanfield, J. P., Wright, A. E., Court, S. D. M., and Green, C. A. (1960). Brit. med. F., 1, 1077.

Higgins, P. G. Boston, D. G., and Ellis, E. M. (1964). Mth. Bull. Minist. Hith Lab. Serv., 23, 93.

Minist. Hlth Lab. Serv., 23, 93. (1963). Ibid., 22, 71.

lzel, A., Parker, L., Patterson, W. H., Cartmel, D., White, L. L. R Purdy, R., Thompson, K. M., and Tobin, J. O'H. (1965). Brit. mea. f., 1,614 .

Kendall, E. J. C., Bynoe, M. L., and Tyrrell, D. A. J. (1962). Ibid., 2,82 .

Lidwell, O. M., and Sommerville, T. (1951). F. Hyg. (Lond.), 49, 365.

Peacock, D. B., and Clarke, S. K. R. (1961). Lancet, 2, 466.

Sutton, R. N. P. (1962). F. Hyg. (Lond.), 60, 51.

Tyrrell, D. A. J. (1963). Amer. Rev. resp. Dis., 88, part 2, p. 77.

I and Parsons, R. (1960). Lancet, 1, 239.

\title{
Malabsorption During and After Recovery from Acute Intestinal Infection
}

\author{
JOHN LINDENBAUM,* M.D.
}

Brit. med. F., 1965, 2, 326-329

In recent years increasing interest has been shown in smallintestinal malabsorption associated with a variety of chronic diarrhoeal diseases. The effect on absorptive capacity of acute intestinal infection, the most common form of gastro-intestinal disease the world over, has received little attention. Many cases of acute enteritis are either too mild to require hospital admission or are discharged from hospital soon after symptomatic recovery. Occasional patients have been reported, however, in whom a sprue-like syndrome associated with malabsorption appeared to follow acute intestinal infection (Achor and Smith, 1955 ; King and Joske, 1960). In the past year we have also encountered two cases in which diarrhoea and loss of weight with malabsorption appeared to follow episodes of acute intestinal infection in previously healthy individuals (Lindenbaum, 1965). Interest in these cases, as well as in the possible relationship of previous bouts of acute bowel infection to the asymptomatic malabsorptive state common in tropical countries (Baker, Ignatius, Mathan, Vaish, and Chacko, 1962 ; Sprinz, Sribhibhadh, Gangarosa, Benyajati, Kundel, and Halstead, 1962 ; Aziz, 1965 ; Lindenbaum, 1965), prompted a study of absorption during and after recovery from acute intestinal infections in East Pakistan. Preliminary results are presented here.

\section{Methods and Materials}

The 95 patients included in this study were Pakistanis admitted to the Pakistan-SEATO Cholera Research Laboratory hospital ward for acute diarrhoeal illness of less than two weeks' duration. Nearly all patients were admitted after only one to two days of acute illness. While most were young adults of either sex, the entire group ranged in age from 7 to 65 years.

In most cases a bacteriological diagnosis was established by culture of rectal swabs. Vibrio cholerae was obtained in 47 ; shigellae (types A, B, or D) in 6 ; and salmonellae (one type D, one type B) in 2 . In four patients who had the classical clinical picture of staphylococcal food-poisoning Staphylococcus aureus was isolated on stool culture and from food recently ingested by all of ther.. Nine patients, from whom no known pathogens were isolated, had an acute severely dehydrating illness resulting in profound circulatory collapse unassociated with rises in antibody titre against Vibrio cholerae (" non-vibrio cholera"). Clinical features of these cases will be reported elsewhere * From the Pakistan-SEATO Cholera Research Laboratory, Dacca 5,
East Pakistan. This report is based on a presentation delivered to the Cholera Research Symposium at Honolulu on 28 January 1965.
(Lindenbaum, Greenough, Benenson, Oseasohn, Rizvi', and Saad, 1965). In the remaining 27 patients, all of whom had an acute gastro-intestinal illness of one to four days' duration not associated with circulatory collapse, no pathogens were isolated despite stool cultures on SS, MacConkey's, gelatin, and tellurite-taurocholate-gelatin agars (" acute gastro-enteritis”).

The five-hour urinary excretion of D-xylose after a $25-\mathrm{g}$. oral dose, as well as plasma-xylose levels at two hours, were measured by the method of Roe and Rice (1948). Normal values for this laboratory for five-hour urinary xylose excretion in asymptomatic Europeans and Americans range from 5 to $10 \mathrm{~g}$. Folic-acid absorption was studied by microbiological assay of serum with Streptococcus faecalis after an oral dose of $40 \mu \mathrm{g}$. of folic acid per $\mathrm{kg}$. Values of $>40 \mathrm{~m} \mu \mathrm{g}$. $/ \mathrm{ml}$. at one or two hours are considered normal (Chanarin, Anderson, and Mollin, 1958). The 24- and 48-hour urinary excretion of vitamin $B_{12}$ was measured after an oral dose of $1 \mu \mathrm{g}$. of ${ }^{58} \mathrm{Co}-$ labelled cyanocobalamin (Amersham) given simultaneously with $50 \mathrm{mg}$. of intrinsic factor. "Flushing" doses of $1 \mathrm{mg}$. of nonradioactive vitamin $B^{12}$ were given at 0 and 24 hours (Schilling, 1953 ; Ellenbogen, Williams, Rabiner, and Lichtman, 1955). Normal values in this laboratory are $9-25 \% / 24$ hours and $13-36 \% / 48$ hours.

Since the tests of xylose and vitamin- $B_{12}$ absorption depend on urinary excretion of the absorbed substances, care was taken to exclude patients with impaired renal function. Oliguric patients were not included in the study. Those who had subnormal urinary xylose excretion associated with two-hour plasma-xylose levels greater than $36 \mathrm{mg} . / 100 \mathrm{ml}$. were considered to have renal impairment and were excluded from the study. Cases whose urinary excretion of ${ }^{58} \mathrm{Co}-\mathrm{cyanoco}-$ balamin during the second 24 hours after the oral dose exceeded that of the first 24 hours were also excluded. Patients who vomited within several hours of the administration of the test substances also were not included.

Stool was collected for gross description and volume measurement over eight-hourly periods. The end of the last eight-hour period before the passage of formed stools of normal appearance was defined as "end of diarrhoea." In some patients studies of xylose, folic-acid, and/or vitamin- $\mathrm{B}_{12}$ absorption were performed soon after admission (after dehydration and circulatory collapse had been corrected with intravenous fluids) in the presence of continuing diarrhoea. Others were first studied during the first week after the end of diarrhoea. In 62 patients serial studies of one or more parameters of absorption were performed. 


\section{Results}

\section{During Diarrhoea}

The results of absorption studies made during diarrhoea due to a variety of gastro-intestinal infections are shown in Fig. 1. Over $90 \%$ of patients studied during the acute infection showed impairment of absorptive function, often marked in degree. Despite the milder degree of clinical illness and dehydration, and much less voluminous stool output in the patients diagnosed as having "acute gastro-enteritis," the degree of impairment of xylose absorption (Table I) was greater in this group of patients than in those with acute cholera (11 of the 16 with cholera were admitted in a state of complete circulatory collapse, without pulse or blood-pressure; none of the 15 with acute gastro-enteritis had circulatory collapse or severe dehydration). The difference between the mean xylose absorptions in the two groups is statistically significant $(P>0.01)$.
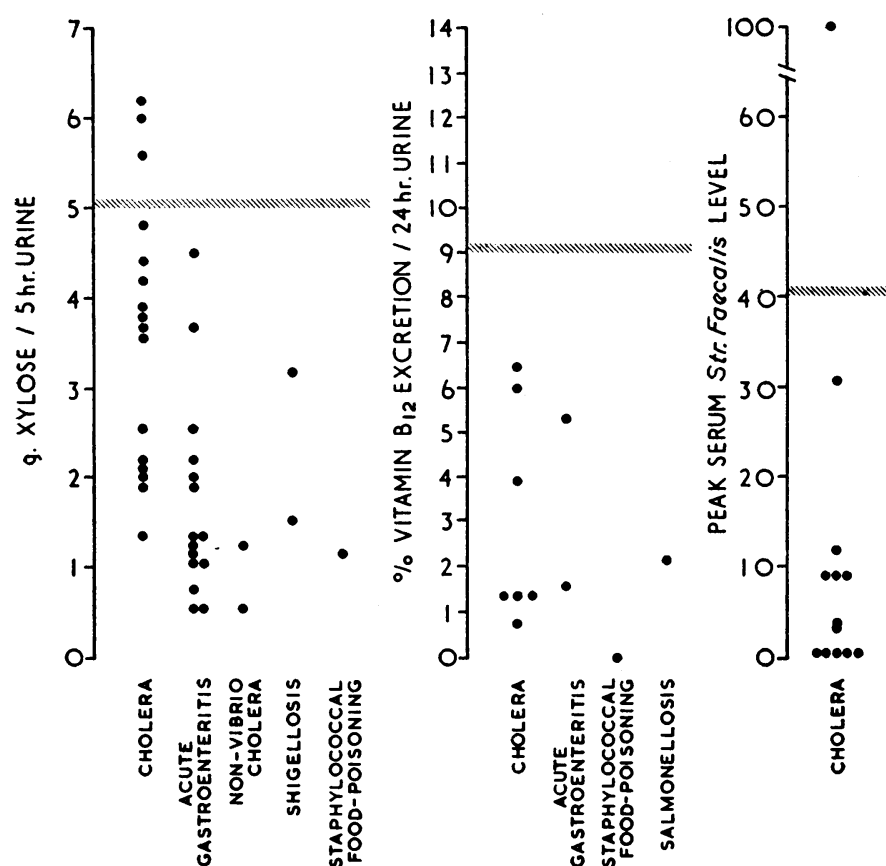

FIG. 1.-Absorption studies during diarrhoea. The shaded lines indicate the lower limit of normal.

TABLE I.-Xylose Absorption during and after Acute Infectious Diarrhoeal Disease

\begin{tabular}{|c|c|c|c|c|}
\hline & $\begin{array}{l}\text { No. of } \\
\text { Patients }\end{array}$ & $\begin{array}{l}\text { Mean 5-hr. } \\
\text { Xylose } \\
\text { Excretion } \\
\text { (g.) }\end{array}$ & S.D. & Range \\
\hline $\begin{array}{l}\text { During diarrhoea: } \\
\text { Cholera } \ldots \\
\text { Acute gastro-enteritis } \\
\text { All patients .. } \quad . .\end{array}$ & $\begin{array}{l}16 \\
15 \\
36\end{array}$ & $\begin{array}{l}3.7 \\
1.8 \\
2.6\end{array}$ & $\begin{array}{l} \pm 1.5 \\
\pm 1.1 \\
\pm 1.6\end{array}$ & $\begin{array}{l}1 \cdot 4-6 \cdot 2 \\
0 \cdot 6-4 \cdot 5 \\
0 \cdot 6-6 \cdot 2\end{array}$ \\
\hline $\begin{array}{l}\text { First week after end of } \\
\text { diarrhoea: } \\
\text { Cholera .. } \\
\text { Acute gastro-enteritis } \\
\text { All patients }\end{array}$ & $\begin{array}{l}34 \\
30 \\
81\end{array}$ & $\begin{array}{l}4 \cdot 7 \\
4 \cdot 1 \\
4 \cdot 3\end{array}$ & $\begin{array}{l} \pm 1.4 \\
\pm 1.7 \\
\pm 1.7\end{array}$ & $\begin{array}{l}2 \cdot 1-7 \cdot 7 \\
1 \cdot 0-7 \cdot 8 \\
1 \cdot 0-7 \cdot 8\end{array}$ \\
\hline
\end{tabular}

Though malabsorption of xylose was present in most patients both during diarrhoea and in the first week of convalescence, the mean xylose levels were higher
in all groups during the convalescent period.

\section{After End of Diarrhoea}

The results of absorption studies carried out during the first week after the end of diarrhoea are shown in Fig. 2. At the time of study the great majority of these patients had undergone complete clinical recovery and were asymptomatic ; a few complained of weakness or mild abdominal discomfort. Malabsorption of xylose was present in $70 \%$ of the patients studied, though it appeared to be slightly less common in the cholera group than in the others. While post-diarrhoeal malabsorption of xylose was often seen in those patients with gastro-enteritis who had minimal clinical symptoms and minimal or no dehydration, it was the rule in those with significant initial dehydration (as reflected by elevation of admission total plasma proteins). Thus 15 out of 23 gastro-enteritis cases with total plasma proteins on admission of less than $9 \mathrm{~g}$. $/ 100 \mathrm{ml}$. showed post-diarrhoeal malabsorption, whereas all of the seven patients with admission plasma protein greater than 9 g. $/ 100 \mathrm{ml}$. had subnormal absorption. All of six patients with "non-vibrio

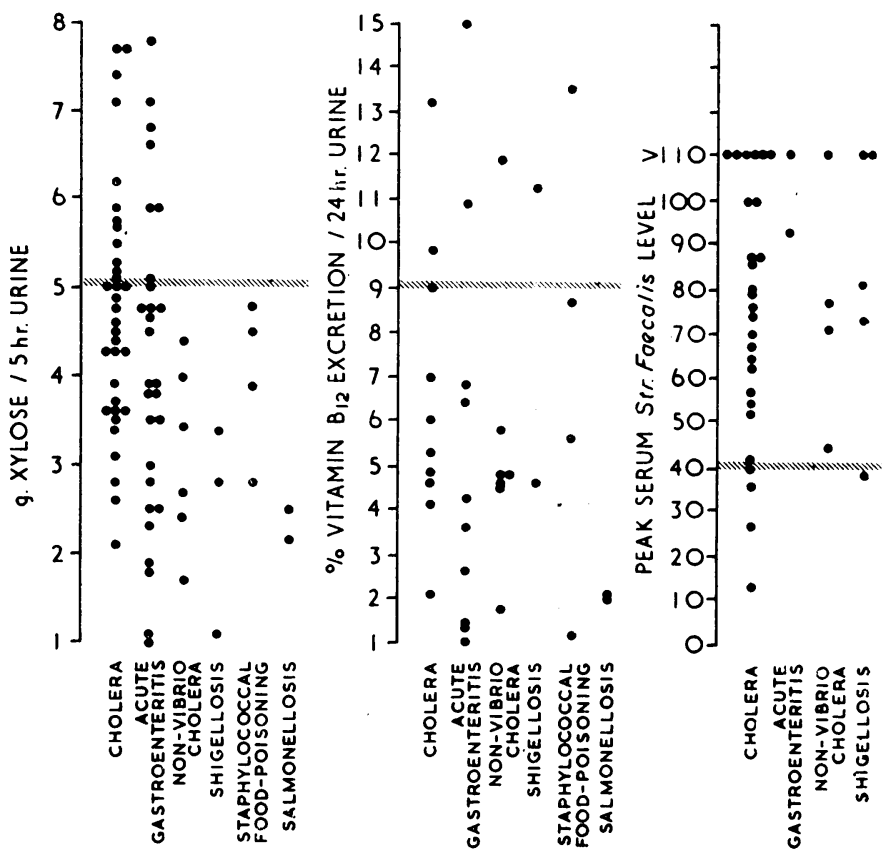

FIG. 2.-Absorption studies during first week after end of diarrhoea. The shaded lines indicate the lower limit of normal.

cholera," admitted in circulatory collapse with severe dehydration, showed malabsorption of xylose after end of diarrhoea. In the cholera cases, however, severity of illness bore no relation to subsequent malabsorption after clinical recovery. Six out of 10 cholera patients who on admission had protein of less than $10 \mathrm{~g} . / 100 \mathrm{ml}$. showed subsequent xylose malabsorption, as did a similar proportion (13 out of 24 ) with admission protein of greater than $10 \mathrm{~g} . / 100 \mathrm{ml}$.

Vitamin- $\mathrm{B}_{12}$ absorption after end of diarrhoea was impaired in $77 \%$ of the cases, and in the small numbers of patients studied there was no evident correlation with bacteriological diagnosis of severity of illness. Absorption of folic acid, however, as measured by Str. faecalis serum levels, was normal after the end of diarrhoea in $93 \%$ of the cases studied.

\section{Serial Studies (Table II)}

The xylose test was repeated once or more at varying intervals after the end of diarrhoea in 51 patients in whom malabsorption of xylose was present when first studied, either during diarrhoea or during the first week after the end of diarrhoea. In 33

TABLE II.-Recovery of Absorptive Function after Acute Intestinal

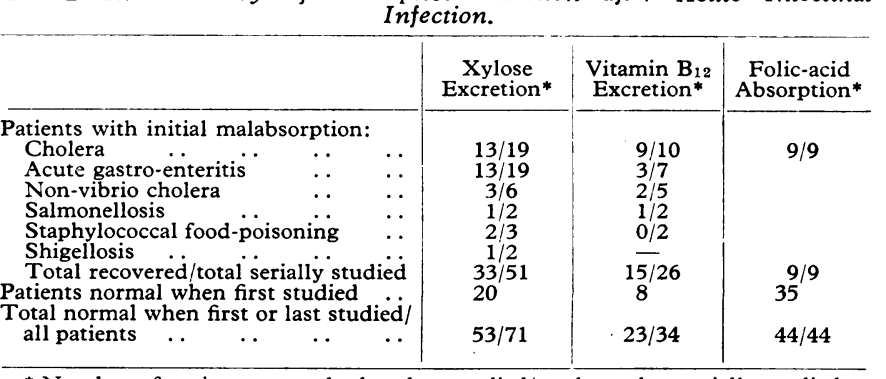

* Number of patients normal when last studied/total number serially studied. 
absorption eventually returned to normal ; in 26 of these a days of the end of diarrhoea. Eighteen patients showed persistent malabsorption of xylose when last studied $(18,26,31,34$, $34,40,42,43,48,52,59,70,180,197,200,338,371$, and 378 days after the end of diarrhoea). Six of these 18 had gastrointestinal symptoms when last studied but only one had lost weight; eight had gained weight, and in the remaining nine body weight was stable.

Serial studies were not performed on 20 patients whose xylose excretion was normal when first studied after diarrhoea had ended. If these patients are included $18(22 \%)$ of a total of 71 patients showed xylose malabsorption when last studied.

Persistent malabsorption of vitamin $\mathrm{B}_{12}$ was also common. Of 26 patients with vitamin- $\mathrm{B}_{12}$ malabsorption during or after the end of diarrhoea only 15 had returned to normal, mostly within the first month after the diarrhoea had stopped. Eleven individuals had subnormal cyanocobalamin absorption when last studied $(14,17,19,22,30,33,36,49,64,138$, and 196 days after the end of diarrhoea). Only 3 of these 11 had gastrotained or had increased. Including those patients who did not undergo serial study because of initially normal vitamin- $B_{12}$ absorption, the prevalence of persistent vitamin- $\mathrm{B}_{12}$ malabsorption in the entire group was $32 \%$ (11 out of 34 ).

In all of nine patients who had malabsorption of folic acid during acute cholera, repeat studies were within normal limits, seven within the first week after the end of diarrhoea.

Patterns of recovery of typical cases where serial studies were done are illustrated in Figs. 3-6.

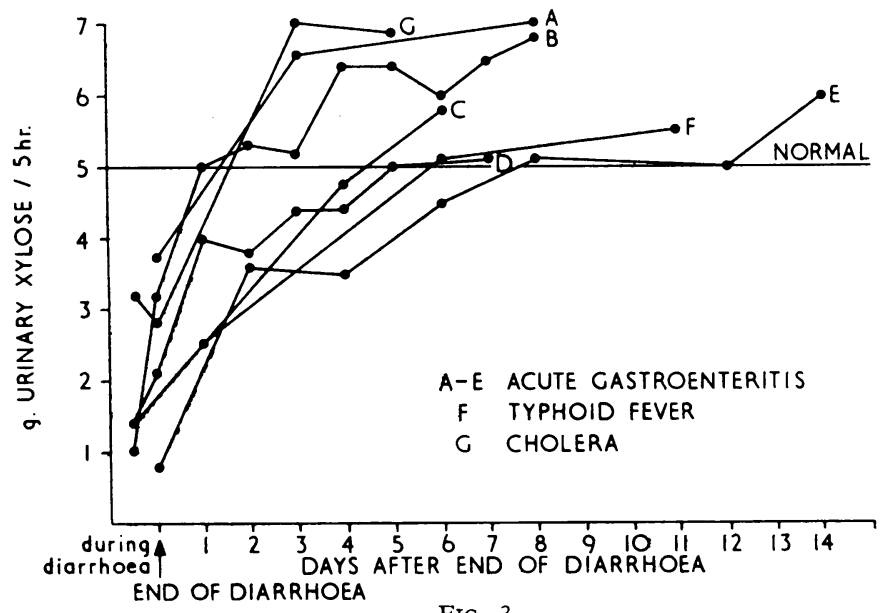
normal urinary excretion of xylose was achieved within eight intestinal symptoms, and in all but one body weight was main-

\section{Antibiotic Therapy}

Ten patients received antibiotic therapy for their acute infection. Of eight patients with cholera treated with tetracycline four showed xylose malabsorption after the end of diarrhoea. Two patients with shigellosis treated with antibiotics showed post-diarrhoea xylose malabsorption.

\section{Discussion}

These findings indicate that moderate-to-severe impairment of absorptive function is the rule during acute intestinal infection due to a variety of pathogenic organisms. In addition, in most patients with acute enteritis of infectious origin subnormal absorptive capacity is present for variable periods of time after the end of diarrhoea and apparent clinical recovery. In most cases absorptive function returned to normal within a week.

Of the substances studied, xylose and folic acid are believed to be predominantly absorbed from the duodenum and upper jejunum (Fordtran, Soergel, and Ingelfinger, 1962 ; Herbert, 1959), while vitamin- $B_{12}$ absorption has been shown to occur almost exclusively in the ileum (Booth and Mollin, 1959). Therefore the absorptive disorder demonstrated in these patients is a widespread one, involving at least carbohydrate and watersoluble vitamins and implicating both the upper and lower portions of the small bowel.

That widespread derangement of function occurs during acute intestinal infection is not an unexpected finding, though the severity of absorptive impairment in some of the mild cases of

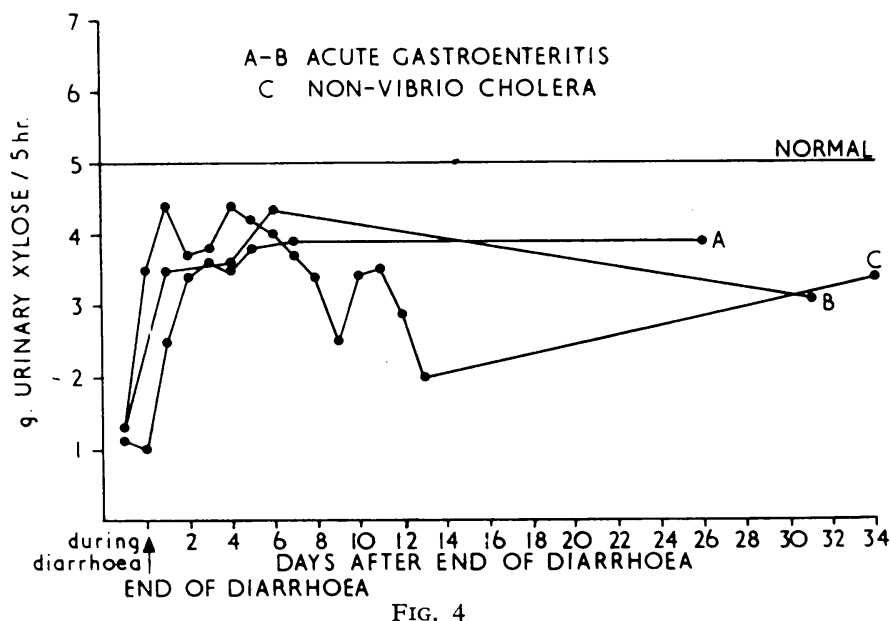

Fig. 3.-Rapid recovery of xylose absorptive capacity. FIG. 4.- Persistent xylose malabsorption.

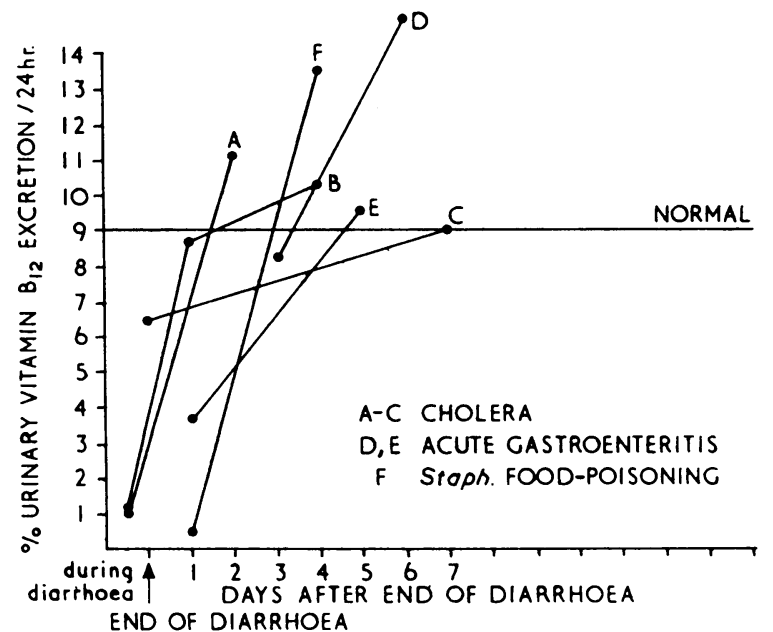

FIG. 5

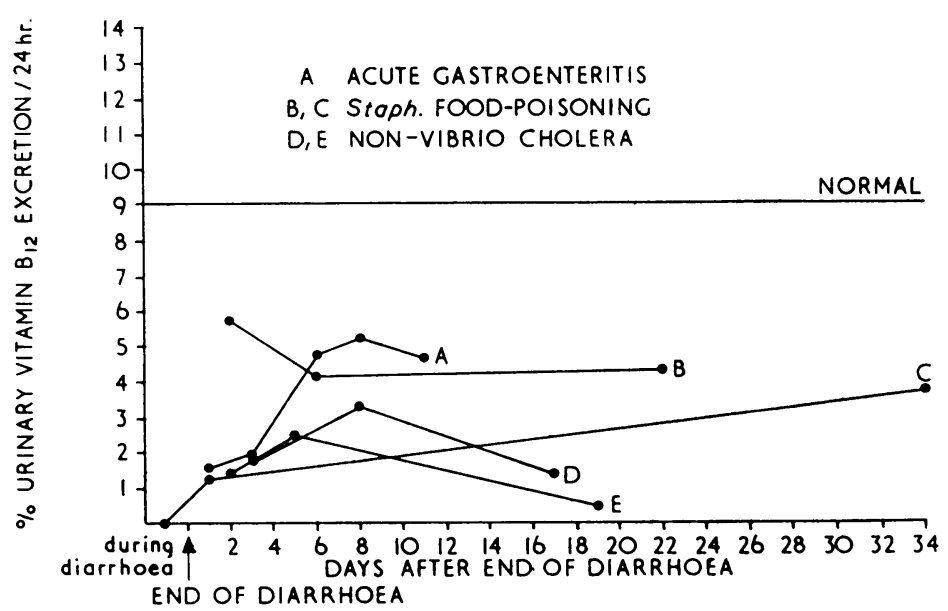

FIG. 6

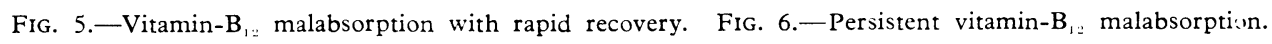


gastro-enteritis was indeed surprising. The degree of impairment was often similar to that seen in patients with idiopathic steatorrhoea and advanced mucosal atrophy. The mechanism underlying the malabsorption present during acute infectious enteritides is uncertain. Decreased transit time, or other effects on bowel function attributable to the mere presence of diarrhoea, cannot account for it. Experimental evidence exists that increased bowel motilit $\ddot{y}$ may actually enhance absorption (Cummins and Almy, 1953). Studies performed in this laboratory on asymptomatic subjects with normal baseline xylose and vitamin- $\mathrm{B}_{12}$ absorption revealed minimal or no change in absorptive capacity during, or in the week following, several days of copious diarrhoea induced by repeated doses of magnesium sulphate (Lindenbaum, 1965).

It is curious that the degree of derangement of intestinal function was greater in patients with "acute gastro-enteritis," including rather mild cases, than in those with full-blown severe cholera admitted in circulatory collapse. This finding may be consistent with present concepts of the pathogenesis of cholera. Recent demonstrations of intact intestinal mucosa on jejunal biopsy during acute cholera (Gangarose, Beisel, Benyajati, Sprinz, and Piyaratn, 1960 ; Fresh, Versage, and Reyes, 1964), as well as the absence of increased protein loss into the gut (Weaver, Johnson, and Phillips, 1948 ; Gordon, 1960), have refuted the formerly held idea that massive mucosal denudation was responsible for the copious rice-water stool passed during the disease. It is currently felt that cholera vibrios remain for the most part in the lumen of the intestine and exert their damaging effect by means of a toxin which results in the passage of rice-water stool (Phillips, 1963).

Malabsorption of one of the test substances in the present study was not always paralleled by malabsorption of the others when all three tests were performed within a day or two of each other (except during diarrhoea, when concomitant impairment of absorption of all three substances was almost universal). During the first week after the end of diarrhoea $77 \%$ of patients studied showed cyanocobalamin malabsorption, $70 \%$ xylose malabsorption, and only $7 \%$ folic-acid malabsorption. The folic-acid-absorption test, in which Str. faecalis serum levels are assayed after an oral dose, may provide a less quantitative measure of absorption than the tests employed involving xylose and vitamin $B_{12}$, in which the percentage of the oral test dose excreted in the urine is measured. A test of folic-acid absorption, in which the percentage urinary excretion of a test dose of the tritium-labelled vitamin is measured, has recently become available (Anderson, Belcher, Chanarin, and Mollin, 1960; Klipstein, 1963). This procedure may provide a more quantitative estimate of absorptive capacity. Future studies are planned to compare the sensitivity of the two procedures in detecting inability to absorb folic acid after recovery from enteric infection.

While an episode of acute infectious enteritis may rarely be followed by a period of prolonged diarrhoea and loss of weight (Achor and Smith, 1955; King and Joske, 1960 ; Lindenbaum, 1965), nearly all individuals who survive an enteric infection appear clinically to recover completely. In most of the patients in the present study malabsorption during and after the end of diarrhoea was transient, with return to normal within one to two weeks after the end of diarrhoea. These findings are consistent with those of Bate and James (1956), who reported depressed amino-acid absorption curves in four infants during the first week after episodes of acute gastro-enteritis, with eventual return to normal. In the present study, however, a significant minority of patients showed persistently subnormal xylose and/or vitamin- $\mathrm{B}_{12}$ absorption, in some cases on repeated study extending several months after the end of diarrhoea. It is planned to continue these studies to determine whether or not full recovery of absorptive function will occur.

The significance of persistent malabsorption in these cases is uncertain. Most of these individuals were free of gastrointestinal symptoms. Sprinz et al. (1962) studied 20 cholera patients in Thailand one year after recovery and found malabsorption of xylose in 9 ; of a control group of 66 " apparently healthy" Thai Army recruits 42 showed xylose malabsorption. Nearly all persons in both groups showed slight or moderate chronic duodenitis or jejunitis on mucosal biopsy specimens. In a survey of healthy East Pakistani employees of the PakistanSEATO Cholera Research Laboratory $40 \%$ were unable to absorb xylose normally (Lindenbaum, 1965). Therefore persistent malabsorption after intestinal infection may merely be a manifestation of an underlying bowel disorder which preceded (or perhaps even predisposed to) the intestinal infection. On the other hand, it cannot be excluded that failure to recover absorptive function after single or repeated bouts of intestinal infection may be responsible for the widespread abnormalities of intestinal structure and function noted in Pakistani and Thai people.

These preliminary findings will be extended by further serial study of selected patients with acute intestinal infection, in whom xylose, folic-acid, vitamin- $\mathrm{B}_{12}$, and fat absorption will be correlated with small-intestinal appearance on mucosal biopsy and $x$-ray examination.

\section{Summary}

Preliminary results of a study of xylose, folic-acid, and vitamin- $B_{12}$ absorption in Pakistanis with acute intestinal infections are presented.

During infection with a variety of organisms, widespread, moderate-to-severe impairment of absorptive function was the rule. Malabsorption was also common during the first week after clinical recovery from infection. In most individuals impairment of absorption was transient. However, some showed continued malabsorption weeks or months after the acute infection. The possible relation of these findings to the prevalence of subclinical malabsorption in East Pakistan is discussed.

This work was supported in part by Research Agreement No. 196802 between the National Institutes of Health, Bethesda, Maryland, U.S.A., and the Pakistan-SEATO Cholera Research Laboratory.

I am grateful to Mrs. Sheila Wickenden for expert technical assistance ; to Dr. Robert S. Gordon, jun., and Dr. Frederick A. Klipstein for advice and criticism ; and to Mrs. Madhabi Ghosh, Mrs. Rekha Sarkar, and other members of the nursing staff for their excellent support.

\section{REFERENCES}

Achor, R. W. P., and Smith, L. A. (1955). Proc. Mayo Clin., 30, 207. Anderson, B., Belcher, E. H., Chanarin, I., and Mollin, D. L. (1960) Brit. F. Haemat., 6, 439.

Aziz, M. (1965). Personal communication.

Baker, S. J., Ignatius, M., Mathan, V. I., Vaish, S. K., and Chacko, C. C (1962). In Intestinal Biopsy, edited by G. E. W.' Wolstenholme and M. P. Cameron, p. 84. Ciba Foundation Study Group No. 14. Churchill, London.

Bate, J. G., and James, U. (1956). Arch. Dis. Childh., 31, 506.

Bate, J. G., and James, U. (1956). Arch. Dis. Childh.,

Chanarin, I., Anderson, B. B., and Mollin, D. L. (1958). Brit! f. Haemat., 4, 156.

Cummins, A. J., and Almy, T. P. (1953). Gastroenterology, 23, 179.

Ellenbogen, L., Williams, W. L., Rabiner, S. F., and Lichtman, H. C. (1955). Proc. Soc. exp. Biol. (N.Y.), 89, 357.

Fordtran, J. S., Soergel, K. H., and Ingelfinger, F. J. (1962). New Engl. 7. Med., 267, 274 .

Fresh, J. W., Versage, P. M., and Reyes, V. (1964). Arch. Path., 77, 529.

Gangarosa, E. J., Beisel, W. R., Benyajati, C., Sprinz, H., and Piyaratn, P. (1960). Amer. f. trop. Med., 9, 125.

Gordon, R. S. (1960). In SEATO Conference on Cholera, p. 54. Dacca Herbert, V. (1959). In The Megaloblastic Anemias, p. 53. Grune and Stratton, New York and London.

King, M. J., and Joske, R. A. (1960). Brit. med. F., 1, 1324.

Klipstein, F. A. (1963). Blood, 21, 626.

Lindenbaum, J. (1965). To be published.

- Greenough, W. B. III, Benenson, A. S., Oseasohn, R. O., Rizvi, S., and Saad, A. (1965). Lancet, 1, 1081.

Phillips, R. A. (1963). Bull. Wld Hith Org., 28, 297.

Roe, J. H., and Rice, E. W. (1948). F. biol. Chem., 173, 507.

Schilling, R. F. (1953). F. Lab. clin. Med., 42, 860 .

Sprinz, H., Sribhibhadh, R., Gangarosa, E. J., Benyajati, C., Kundel, D., and Halstead, S. (1962). Amer. F. clin. Path., 38, 43.

Weaver, R. H., Johnson, M. K., and Phillips, R. A. (1948). ₹. Egypt. publ. Hith Ass., 24, 5. 